marked increase in tumour incidence when combined with a given carcinogen. Electron microscopy of the epidermal cells of the interfollicular areas of a mouse's back indicate that marked changes in cell contacts with intercellular gaps and bridges are produced by the promoting agents. Surface-active agents which do not act as promoters, on the other hand, lead to an actual hindrance of proliferation and increased regions of close contact between the cells.

Dr. E. H. Mercer (London) also described some of the valuable results he has obtained by high-resolution electron microscopy of cell contacts. Electron micrographs of cell membranes (Birbeck and Mercer) indicate that they consist of a layer structure about $60 \mathrm{~A}$. thick which could correspond to the lipid lying between protein layers, as proposed by Prof. J. F. Danielli. The membranes are generally separated by a distance of 150-200 A., suggesting the presence of a cementing material between the cells. Anaplastic tumours often show changes in their cell contacts as compared with normal tissues. They may show a convoluted surface with only small areas of contact; the contacts are more like those of normal cells during the early stages of tissue formation. The electron microscopy, therefore, supports the view that the surface properties of tumour cells are changed in comparison with the normal cells from which they are derived.
In conclusion, mention may be made of two other techniques which are being applied to the problem of cell movements and cell contacts. Dr. H. Harris (Oxford) described a simple but most effective method which he has applied to the study of groups of white blood cells. A long exposure is made with dark-field illumination. On subsequent development of the plate, the paths of the moving cells are recorded as streaks on the photographic emulsion. This technique is particularly useful for the study of a taxis affecting the over-all direction of cell migration.

Finally, Dr. R. J. Goldacre (London) described an approach based on the use of electronic models. In normal growth and maintenance the transfer of information from cell to cell evidently occurs. Direct contacts between the cell membranes appear to play a part in this, at least in the early stages of development. An electronic model consisting of units ('cells') which can stimulate and be stimulated by others can be designed. By connecting the units together in different groups, various complex patterns of interest in morphogenesis are generated in the system; for example, patterns with polarity, discrete differences between neighbouring units, etc. On the basis of such a picture, it would be expected that a small loss of cell - cell interaction, arising from surface changes, could readily lead to abnormal and uncontrolled growth in tumour tissues.

E. J. Ambrose

\title{
PREDICTING ACADEMIC SUCCESS
}

$\mathrm{T}$ HE purpose of a recent investigation by Sigvard Rubenowitz, of the Swedish Council for Personnel Administration, Gothenburg, was to determine the weights which have to be assigned to different tests and biographical data in order to predict success in academic studies*. The freshmen at the three universities in Gothenburg in 1954 were invited to take part in the investigation, the results of which would later be related to success at university as measured by examination results. Freshmen were chosen as subjects for the investigation in order to avoid bias in the results of the tests arising from different academic studies. In all, 440 , or 62 per cent, of the freshmen responded to the invitation.

After two years, information about examination results was collected and this was related to the data collected two years earlier.

The data collected and the tests which were given to the students were: (1) grades in the matriculation examination; (2) study habit assessments; (3) intelligence test marks; (4) technical test marks; (5) mathematical-technical test marks ; (6) organization test marks; (7) details of interests; (8) psychodiagnostic test assessment; and (9) attitude assessment.

Analysis of the results showed that of 43 female students who studied languages and 18 who were studying psychology the validation data in Table 1 were obtained.

It became clear that, for languages, more time is required for study than for other subjects. In addition, a significant correlation exists between intellectual and matriculation results on one hand and success in language studies on the other. The study habit also appears to be of great importance

* Occupational Psychology, 32, No. 3 (July 1958). in the study of languages. With psychology, general intelligence, together with those qualities which find expression in a good matriculation result, are not of such decisive importance as are certain mathematical technical aptitudes and some characterological factors that are measured by the Zulliger test.

Table 1

\begin{tabular}{|l|c|c|} 
& $\begin{array}{c}\text { Languages, } \\
\text { 43 students }\end{array}$ & $\begin{array}{c}\text { Psychology, } \\
\text { 18 students }\end{array}$ \\
\hline Grades in matriculation examination & 0.43 & 0.12 \\
Study habit inventory & 0.38 & 0.17 \\
Intelligence test & 0.40 & 0.28 \\
Technical test & 0.17 & 0.31 \\
Mathematical-technical test & 0.06 & 0.23 \\
Organization test & 0.04 & 0.28 \\
Psychodiagnostic test & 0.15 & 0.37 \\
Attitude assessment (the 'rigid' pole) & 0.21 & 0.25 \\
\hline
\end{tabular}

With certain male students the subject groups that formed the object of the validation were languages, psychology (philosophy), mathematics (statistics) and zoology (botany). The students of mathematics and statistics were, in general, superior to all others and above all in their intelligence and mathematicaltechnical ability. The male language students, like their female counterparts, made a significantly poor showing in their examination results.

The validation data in Table 2 were obtained from this inquiry.

Comparing these results with those for female students, the same trend is found except in the case of the matriculation result; this was of most value in prognosis for female students of languages, whereas for male students its value is highest for prognosis of psychological studies. 
Table 2

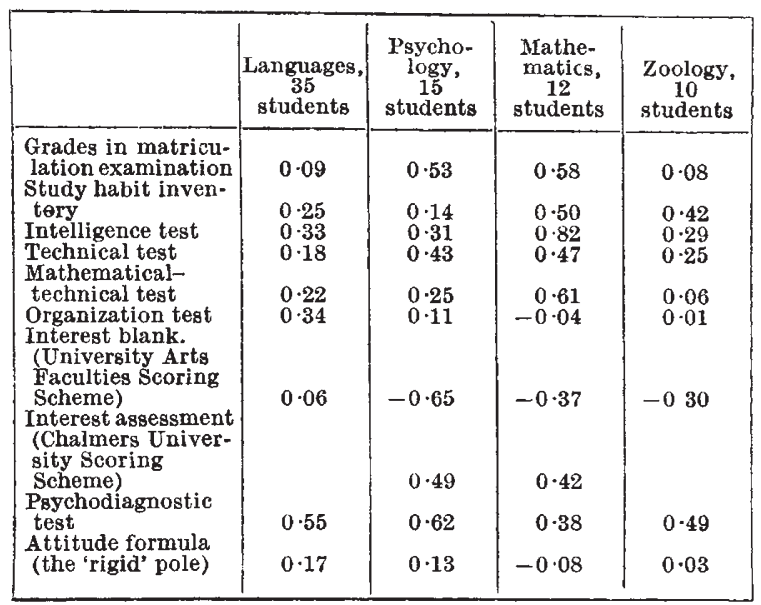

At the University of Technology the coefficients of validity in Table $\mathbf{3}$ were obtained.

It appears that the matriculation examination has a considerably higher prognostic value for these than for those at the University (arts faculties), probably because the courses at the former have to be followed closely and in many respects resemble pre-matriculation studies. For this reason, the matriculation examination can be considered as a job sample test.

A combination of the matriculation results and tests would form the most suitable instrument of prognosis for these students, provided that the
Table 3

\begin{tabular}{|l|c|}
\hline & 219 students \\
\hline Grades in matriculation examination & 0.67 \\
Study habit inventory & $0 \cdot 30$ \\
Inteligence test & 0.15 \\
Technical test & 0.22 \\
Mathematical-technical test & $0 \cdot 32$ \\
Organization test & 0.09 \\
Interest blank & 0.20 \\
Psychodiagnostic test & 0.22 \\
Attitude assessment (the 'rigid' pole) & 0.01 \\
Entrance qualifications (matriculation grades + & 0.52 \\
previous factory experience) & 0.77 \\
Best combination of six prognostic variables & \\
\hline
\end{tabular}

multiple regression calculation stands up to cross validation in a renewed investigation.

At the University of Economics the criterion used was the average result in all the subjects passed. The coefficients of validity were as shown in Table 4 .

\begin{tabular}{|l|c|}
\hline \multicolumn{2}{|c|}{ Table 4 } \\
\hline Grades in matriculation examination & 49 students \\
Study habit inventory & $0 \cdot 22$ \\
Intelligence test & $0 \cdot 46$ \\
Technical test & $0 \cdot 18$ \\
Mathematical-technical test & $0 \cdot 31$ \\
Organization test & $0 \cdot 34$ \\
Interest blank & $0 \cdot 18$ \\
Psychodiagnostic test & $0 \cdot 16$ \\
Attitude assessment & $0 \cdot 36$ \\
Best combination of seven prognostic variables & $0 \cdot 04$ \\
& $0 \cdot 77$ \\
\hline
\end{tabular}

The study habit inventory had the highest validity here, followed by Zulliger's psychodiagnostic test and the mathematical-technical test. The low validity of the matriculation result is worthy of note.

\section{INDUSTRY AND GOVERNMENT IN CANADA}

TN his Messel Lecture, "Industry and Government in Canada", before the Society of Chemical Industry at Montreal on September 15, the Rt. Hon. C. D. Howe, P.C., reviews changes in the responsibilities of government and the attitude of industry during the past fifty years. When he came to Canada as a graduate engineer in $1908, \mathrm{Mr}$. Howe said that most people regarded activities at Ottawa as remote and of very little personal concern. Now, an industrial revolution and relatively sudden highly scientific industrial and military developments, with the rise of the Welfare State, had transformed the scale and character of government administrative responsibility. While the population had grown from 6.5 million to 17 million, government expenditure had multiplied about twenty-five times and was now 5,272 million dollars a year. Mr. Howe believed that most Canadian business men to-day recognized that the public demanded services which only government could provide and that many of them not only tolerated government activity but also were prepared to admit that government action could promote the prosperity and welfare of the country. There had also been a similar improvement in the attitude of government towards business in Canada, and his experience as a Minister during 1935-57 led him to believe that the role of industry and commerce in society was better understood than it had been before.

Mr. Howe then referred to some changes in the administrative structure and notably the appearance of what is known in Canada as the Crown Corporation, on which experienced business men gave part-time service as directors. This pragmatic device, analogous to the public corporation in Britain, had received much more extensive use since 1935, and after noting the establishment of the National Research Council as a Crown Corporation, out of the Advisory Council on Scientific and Industrial Research formed in 1916, Mr. Howe described a few examples including some of the twenty-eight Crown Corporations formed during the Second World War in the Department of Munitions and Supply, of which he became Minister in 1940. During and after the War the Department functioned directly as the sole procurement agency for the three Armed Services, and he thought that the Crown Corporation had proved itself to be an efficient device for enabling government to cope with certain new responsibilities thrust upon it by an advancing technology. Generally, he thought that the government should not enter into any business that is competitive with private industry, but certain responsibilities that could not be directed to private industry and certain other responsibilities which no private industry was prepared to undertake were most efficiently discharged through a Crown Corporation, nor did he think the device need be abandoned if private industry later entered the field. He also thought that the Crown Corporations had made an important contribution to better understanding between government and business, and in his twenty-two years experience it had been amply demonstrated that complete co-operation between government and business is a prerequisite of national prosperity. 